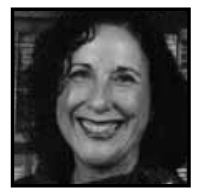

\title{
Identity and Creativity: Putting Two and Two Together
}

\author{
Margaret Louise Dobson
}

\begin{abstract}
"Questions, not method, are the heart of research" (Hendry, 2010, p. 73). Prompted by untutored intuition in the form of questions generated from two stories about teaching and educational leadership, this investigation looks for insights, not answers, to the mystery of identity and creativity. Putting two and two together reveals an intangible "in-between" (Arendt, 1974); distinguishes thinking and knowing (Arendt, 1971); elucidates intuition and intellect (Bergson, 1998/1907); exposes emotion and feelings as vital aspects of reason (Damasio, 1994; 1999); and conspires to revitalize the meaning and purpose of education.
\end{abstract}

\section{Introduction}

$\mathrm{n}$ a daring attempt to probe the long-standing mystery of what (or who) constitutes identity and creativity, I shall begin by re-examining two narrative pieces I recently wrote to highlight particular events stemming from my former teaching and educational leadership experience. The two accounts are intended to form a backdrop for the present investigation as well as to elicit useful prompts to propel my ongoing doctoral work, and to hopefully turn up additional clues to substantiate the intimate relationship I detect between identity and creativity. Understanding the nature of this connection may hold important implications for education.

"Questions, not method, are the heart of research" (Hendry, 2010, p. 73).The process of inquiry as I have come to know it has always been instigated by untutored intuitions in the form of questions. Past forays into questions of identity and creativity 
have taught me, through trial and error, that the mystery I am investigating will not lend itself readily to a step-by-step procedure; nor will the conundrum succumb easily to attempts to unravel or compile information. Au contraire, investigative work of this nature has repeatedly shown that identity and creativity shy away from positivistic analyses, categorizations, and definitions. I have discovered, instead, that meaningful insights "occur" in the same manner that Gadamer describes the happenstance of hermeneutics, the phenomenon of understanding that "goes beyond the limits of the concept of method as set by modern science" and "belongs to human experience of the world in general" (2010, p. xx). I suspect, again from past experience, that any clues to the mystery I am presently investigating will tend to reveal themselves by sudden surprise, and only if I am attentive to the rigorous demands of "perceptivity," defined by Barone and Eisner as "seeing what most people miss" (1997, p. 93). No longer trying to figure it all out, I am interested in putting two and two together based on my lived experience of the mystery under investigation.

For the inquisitive process I describe, storytelling has become one of the best ways I know for paying close attention to the regular, irregular, and downright peculiar aspects of lived experience. A recounting of events can expose significant truths that may otherwise be overlooked. Most importantly for research purposes, storytelling generates more questions than answers, and provides the necessary time and space for introspection and reflection.

The following two stories took place several years apart: one many years ago in Simcoe County, Ontario; and the other, more recently at St. Anthony's College at Oxford University. The leitmotiv in both scenarios is the mystery presently under the magnifying glass, namely identity and creativity. You may recognize aspects of your own experience in the reflection.

\section{Stumbling Upon the Wow! Factor}

Like most young people starting out in their careers, I didn't give any thought whatsoever to the meaning and purpose of the profession I was about to enter. Compared to my preoccupation with lesson plans and classroom management skills, or lack thereof, the intrinsic meaning of education lay carefully and conveniently buried beneath the fascinating and daunting details of my extrinsic to-do list. For all I knew, or cared to know at the time, I was hired by the Simcoe County Board of Education to do "a job." My job was simply to teach French to high school students according to the 
latest methods prescribed by the ministry-approved program that was handed to me on day one. The program was part of a broader curriculum that was part of a larger school system designed and operated by the Ontario government, and legislated by the Canadian government to be delivered according to provincial standards by the local school board officials. For my small part in the big picture, it was all I could do just to do my job. C'est déjà ça! Little by little, and quite by surprise, however, I began to discover I loved my job! In fact, I took to the classroom like a duck to water. To this day I can remember the surge of confidence I felt when my first district inspector's report came back: "Natural born teacher."

Because I was only a few years older than my Grade 13 students, I learned very quickly that authority in the classroom comes from personal authenticity, not from expertise or know-how which was understandably still very much under construction. Despite my newness to the role, I made sure that my lesson plans were as good as done; my methodology comme il faut; and my students' test results commendable. For reasons beyond the obvious quantifiable predictable factors for success, however, there was an unpredictable yet undeniable wow! factor to be taken into serious account: my students loved their French classes; and incidentally, so did their French teacher! Whatever the content of matières, the French class environment was consistently alive with joie de vivre. We were on to something that I definitely did not learn at the Ontario teachers' college! And like a grass fire, word of this mysterious, mystical, unquantifiable, unqualified, unknown wow! factor got around. I was asked by the school officials to spread that fire, and was appointed to the role of Supervisor of Moderns for the County to do just that. Soon I was invited to co-author the highschool segments of a new K-13 audio-visual program with a team from the Ontario Ministry of Education. And yet another inexplicable fait accompli led to facilitating teacher workshops in Canada and the United States, and to animating an ETV program for teaching FSL in classrooms across Canada. The teaching "job" that I was initially hired to do had quickly morphed into a juggernaut of responsibilities for which I didn't really, at heart, feel prepared. How do I teach a wow! factor phenomenon that I had only just recently, just by accident, stumbled upon?

At one of the workshops I came face to face with the core issue, or problem, that I had intuited. In my usual animated interpersonal style of presentation, I could tell that the response of the audience was for the most part warmly receptive to the methodology of the contexte globale philosophy I was advocating. Suddenly, however, and seemingly out of the blue, one of the teachers whose tone of voice and rigid posture immediately let me know that she was not happy with the "newest and latest," stood up in a rage. She was not just angry; she was furious! "What about the 
grammar?" she yelled at me from her entrenched position half way back in the auditorium. For this teacher, what mattered were the mechanics of the language, "the grammar," both literally and figuratively. There was no trying to convince her otherwise.

I continued to teach and to lead in a variety of privileged positions and circumstances in Ontario and Quebec schools, but the impact of that incident, along with the questions and theoretical hunches evoked by the events of the first few years of my career, have continued to haunt me. How do I advocate the wow! factor when it is so difficult, if not impossible, to define and explain the intangible within the parameters of an institution firmly established in the concrete traditions, concepts, and principles of utilitarian and instrumental aims, where raison d'être (meaning and purpose) has been eclipsed by savoir faire (skills and knowledge)? Who wants to be reminded that there is more to education than learning "the grammar" or getting "the job"? How do I find ways to convey in a scholarly manner the invisible, immeasurable, nuanced, creative aspects of education? Does it matter anymore who is doing the teaching, or who is doing the learning? Does it matter as long as "the job" gets done according to standardized tests and ministry guidelines? How do we integrate what we do with who we are in ways that will allow not just the acquisition of knowledge and competencies, but also the flourishing of the human spirit? Can the wow! factor that seems to have everything to do with joie de vivre and passion for what we do in relationship with others be taught? How do we create conditions for a creative interplay between teacher and students that can evoke mastery and mystery?

Before attempting to respond to the pressing questions generated from the above narrative, I want to present the second account for the purposes of expanding the base and opening up a larger arena for a discussion of related factors. Please fast forward to an international gathering of educational leaders- “"The Superintendency and The Principalship" —invited in 2004 to present papers on "Designing Leadership Practices for the Future of Public Education" at the Oxford Round Table on Education at St. Anthony's College at Oxford University.

\section{Is There Room for Creativity in Our Schools?}

An air of scholarly tradition pervaded the historical setting of the prestigious Oxford Union, the ambiance tangibly influencing the formality of the day-long proceedings. Each morning we would enter the hall quietly, almost reverently, and take our appointed places around the dark hand-carved oak tables. Delegates' words sounded especially weighty in the echoing chambers of this hallowed space. 
Somewhat dishevelled from having just abandoned his early morning duties inspecting Oxford schools, Bill Laar burst through the door and into the chambers like an unexpected gust of wind. Laar had come to speak on his scheduled topic, "Is There Room for Creativity in the UK?" Along with Laar, the proverbial "breath of fresh air" blew strong and mighty into our midst. The rather stuffy atmosphere of the previous deliberations was stirred up and undone in one fell swoop. The timbre of the 2004 Round Table on Education was changed for the duration.

Laar was grappling with the alarming statistics of the teacher drop-out rate in the United Kingdom (UK), and the resultant chaos for British schools. He also named many of the all-too-familiar problems faced by public education everywhere: the underfunding and overtaxing of human and material resources; the intolerable pressures on teachers and students exerted by society's high expectations for inhuman results; the as yet unmet challenges to truly meet the needs of a diverse student population; governments' insistent and pervasive implementation of external standardized testing routines despite the cry of educators to the contrary; and the ubiquitous, unrealistic, and often misaligned, top-down reforms aimed at schoolimprovement coupled with the exponential increase in numbers of parents choosing private schools over public schools-or home-schooling or un-schooling (the latest trend) - in their attempt to protect their children from the real or perceived "degradation" of the public education system.

Laar's presentation, however, wasn't just about what was tragically wrong with the present-day situation. His talk soon took an impassioned turn into an envisioning of what education could/should really be all about, namely, creativity. Is there room for creativity in the UK, or anywhere else for that matter? Laar's vision lauded a well-rounded education that would include every possible kind of exposure to every possible kind of human experience. Through the prolific examples and metaphors he offered, we could literally feel the critical importance in the developing life of a young boy or girl of experiencing the thrill of sailing a boat into the wind, for example; or the sense of accomplishment in learning to play a Mozart minuet on the piano, or the joy of participation in team sports or a school play or musical production.

"Yes, but ... creativity costs money that cash-strapped public schools just don't have," was the gist of the initial comments from the delegates who were only too well versed in the bottom-line of school administration. "It's the politicians and the economists who hold the purse strings; and, therefore, make the decisions as to what constitutes an education, not educators," continued the thread of conversation. The irony did not go unnoticed: as productivity and fiscal responsibility continue to 
squeeze out "expensive" creativity from the public school curriculum, the costs of public schools' problems appear to be on the rise in equal or greater measure.

It was unanimous. We agreed that creativity, in whatever form it takes, is absolutely essential to education. "Creativity is a way of living; it's a way of being human," declared one delegate. "Is there room for spirit in our schools?" asked another. Rather than continue to complain and bemoan the fact (as we were) that education is no longer in the hands of educators, but under the dictates of policy-makers who have little or no interest in creativity, it was thought by some delegates to be high time that we, as educational leaders, roll up our sleeves and take back our calling. There was talk of drawing up a collective statement to that effect that would represent the delegates' unequivocal agreement on the essential place of creativity in education. A pre-programmed, heavily packed agenda and lack of time-the usual culprits-prevented that statement from ever being written. Perhaps, in some small way, the doctoral work in which I am presently engaged will help to make that unwritten statement one day a reality.

The 2004 Oxford Round Table on Education has not only raised a roof in the Oxford Union, it has also raised several more questions of critical importance to the investigation at hand. What (or who) constitutes "creativity"? Can creativity and productivity work together in harmony in our schools, each potentially enhancing and enriching the other? Does creativity have to cost money that cash-strapped schools just don't have, or is creativity a luxury only for the privileged few who can afford it? And finally, how could/would creativity and all that creativity might entail in the UK and elsewhere contribute to nurturing and nourishing the complexity and diversity of a worldwide web, the interconnected, interdependent ecological, political, social, and economic reality of the 21 st century?

\section{Enter Hannah Arendt}

Hannah Arendt (1974), in her remarkable book, The Human Condition, has given much thought to the questions I am posing. She says that the source of creativity springs indeed from who we are and remains "outside the actual work process" as well as independent of what we may achieve (p. 211). This is a significant finding in light of the intuitive question at the heart of this paper: Is there a link between identity and creativity? The source of creativity, according to Arendt, springs from the identity of the person, who. A subjective completion of critical importance to this 
investigation has thus been revealed. To further elucidate the subject, I again quote Arendt who says that who "is the unchangeable identity of the person" (p. 193).

Arendt's perspective contradicts the widely accepted view of identity that is central to most contemporary Western educational programs and reforms. Stuart Hall, for example, says that identity is "constructed"; and that the notion of an integral, originary, and unified identity, or what he calls "essentialist concepts," has been deconstructed and "put under erasure" (1996, p. 2). The growing ideal in modern society in this regard, says Charles Taylor, is a human agent "who is able to remake himself by methodical and disciplined action" (1989, p. 159).

Based on my early teaching experiences, I find Arendt's essentialist perspective of the authentic "unchangeable" identity, who, to be the most plausible for explaining the source of creativity, or, in this case, the wow! factor. Moreover, Arendt's following explanations à propos the mysterious occurrence make utter sense to me thanks to the resonance of my personal experience with the phenomenon she describes. Arendt explains that when people get together as who-aka "essential" identity_and not what-aka "constructed" identity—an "in between" opens between them. The "in-between," according to Arendt (1974), is no less real than the world of things we visibly have in common. Arendt maintains that only love (respect in the public realm) is fully receptive to who somebody is. I ascertain, therefore, that the unpredictable, uncalculated, unplanned wow! factor that transpired in my classroom was the result of the inadvertent presence of who-perhaps due to the very fact that skills and know-how were still under construction, and assumed-identity-asteacher as yet under-developed-that allowed the respectful "in between" to open between the teacher and her students. If the wow! factor is the "real" we have in common, where's the mystery in that? "What about the grammar?" I hear the resounding echo of the teacher's angry protest.

How differently we might approach teaching and learning if we were to seriously consider the premise that human identity is not something that is socially, politically, and economically "schooled," "storied," and/or "constructed," but that human identity is inherently and originally generated as who one is, the source of creativity. Arendt says that the purpose of her book is to inspire a generation of "job holders" to "think what we are doing" $(1974$, p. 5). Aligning the purpose of the present investigation with the purpose of The Human Condition, I ask who is thinking and who is doing; who is the source of creativity? The pivotal question that remains at the heart of the inquiry, therefore, is "Am I an 'essential' who or a 'constructed' what?" Or, "Am I both?" My newly educated guess is that the ineffable mystery of creativity — the wow! 
factor-may be understood in the putting of two and two together. Arendt's (1971) following distinction between thinking and knowing complicates the double entendre and amplifies the resonance of the complements under investigation.

\section{Thinking and Knowing}

In "Thinking and Moral Considerations: A Lecture," Arendt (1971) gives credit to Kant for the important distinction she makes between thinking and knowing, "between reason, the urge to think and understand, and the intellect, which desires and is capable of certain verifiable knowledge" (p. 422). Arendt sees the activity of thinking as "the habit of examining and reflecting upon whatever comes to pass, regardless of specific content and quite independent of results ..." (p. 418). Knowing, on the other hand, according to Arendt, is results-oriented and "no less a worldbuilding activity than the building of houses" (p. 421). I make the connection between knowing and the results-oriented, world-building, goal-driven activities of the dominantly instrumental-utilitarian program of schooling. In the case of the wow! factor narrative, knowing pertains to subject content and material, lesson plans, and classroom management skills and strategies. Thinking, on the other hand, goes beyond knowing, in that thinking "deals with invisibles and is itself invisible, lacking all the outside manifestation of other activities" (p. 433). Arendt cites Socrates as having used the metaphor of the wind for thinking. In reference to the first narrative piece, I make a connection between Aristotle's wind that does, un-does, and re-does thought, and Arendt's (1974) portrayal of who and Taylor's (1989) citations of essential identity. Any "natural born" teacher knows that it is good practice to have at hand sound knowledge of subject material, lesson plans, teaching skills, and classroom management strategies in the same way that the sailor must have a boat, rudder, sails, maps, compass, and the wherewithal to sail the high seas. However, the teacher and the sailor worth their salt both know that it is the wind that determines the momentary course of action, the momentum, and the nature of the voyage into life's perplexities or into the teaching of French grammar! The personal authority and freedom to act (or teach) is released in perpetual thinking. From that perspective, perhaps it could also be deduced that conditioned behaviour and trained professing is determined and held in check by conceptualized knowing.

"If it should turn out to be true that knowledge ... and thought have parted company for good, then indeed we would become the helpless slaves, not so much of our machines as of our know-how..." (Arendt, 1974, p. 3). This is an alarming prediction 
in light of the fact-again according to Arendt - that we have lost who we are in what we do. It would seem from the above warning that thinking is an integral part of the authentic who that has been lost in the artificial what of man-made constructions. In carrying this notion further, I make a distinction between education and schooling that is critical to this investigation. It would seem from the above consideration, that thinking (thought) is central to creativity, and can be drawn forth (e-duced) through education; while knowing (cognition) is central to productivity, and can be taught (in-duced) through schooling. In putting two and two together, I begin to discern the links between "essential" identity (who), thinking, creativity, and education; and "constructed" identity (what), knowing, productivity, and schooling. Education and schooling are not the same. Has schooling overtaken education? Have education and schooling parted company for good?

Along with the distinct, yet complementary, essential who and the constructed what of identity, and the distinct, yet interrelated and interdependent aspects of thinking and knowing, another related duo of distinction conspires to both complicate the matter and elucidate the mystery. The next elusive pair to come forward for examination is intuition and intellect.

\section{Reigniting the Lamp of Intuition}

Henri Bergson (1998/1907), an eminent French scientist turned philosopher, examines the complexity of relationship between intuition and intellect. Bergson says that intuition, what he calls, "the best part" of the power of consciousness, has been sacrificed to intellect. The following excerpt from Creative Evolution illustrates the resonance I detect between Bergsonian theory of human consciousness and Arendt's (1971) reinvigoration of the Kantian distinction between thinking and knowing:

Consciousness, in man, is pre-eminently intellect. It might have been, it ought, so it seems, to have been also intuition. Intuition and intellect represent two opposite directions of the work of consciousness: intuition goes in the very direction of life, intellect goes in the inverse direction, and thus finds itself naturally in accordance with matter. A complete and perfect humanity would be that in which these two forms of conscious activity should attain their full development. (Bergson, 1998, p. 267)

Bergson explains what he means when he says that intuition is the "best part" of the power of consciousness. He says that it is only when we place ourselves in intuition 
that we can pass from intuition to intellect. From the place of the intellect we shall never be able to pass to intuition, he says. Yet, it is the intellect that has dominated intuition in the present-day humanity of which we are a part. The consequence of the pre-eminence of the intellect in human affairs is explained in the following continuation of the above citation:

This conquest, in the particular conditions in which it has been accomplished, has required that consciousness should adapt itself to the habits of matter and concentrate all its attention on them, in fact determine itself more as intellect. Intuition is there, but vague and above all discontinuous. It is a lamp almost extinguished, which only glimmers now and then, for a few moments at most. (p. 268)

Bergson suggests that what he calls "fleeting intuitions" ought to be seized by philosophy, first for the purposes of sustaining them, and then for expanding them and uniting them together. According to Bergson, the rationale for advancing in this work stems from the fact that the more one advances, the more one will perceive that intuition is mind itself and, in a certain sense, life itself. Thus, says Bergson, is revealed "the unity of the spiritual life" (p. 268). And, thus another significant two are put together by Bergson in a compelling argument for the complementary and equal partnership of distinct opposites.

\section{Emotion, Feeling, and Reason}

The French word intuition more closely approximates the English word "feelings" than that of the word "instinct" which is the commonly used English translation to be found in Bergson's work. According to neurologist and neuroscientist Antonio Damasio (2003), until only recently little has been understood about the nature of feelings. "Elucidating the neurobiology of feelings and their antecedent emotions contributes to our views on the mind-body problem, a problem central to our understanding of who we are" (p. 7). Moreover, maintains Damasio, "understanding what feelings are, how they work, and what they mean is indispensable to the future construction of a view of human beings more accurate than the one readily available today." Why? "Because the success or failure of humanity depends in large measure on how the public and the institutions charged with the governance of public life incorporate that revised view of human beings in principles and policies" (p. 8). 
According to Damasio, "Feelings form the base for what humans have described for millennia as the human soul or spirit" (1994, p. xvi). Damasio sees identity and creativity in the same light that Arendt (1974) and Bergson (1998) envision a complete and perfect humanity in which both aspects of consciousness are fully developed and working together. For Damasio, feelings are the connectors; storytelling and the Arts the inducers, a way into "the homeostatic refinement ... the biological counterpart of a spiritual dimension in human affairs" (2010, p. 296).

The most vexing of all questions writes Damasio in Descartes' Error is this: "How is it that we are conscious of the world around us, that we know what we know, and that we know that we know?" (1994, p. xvii). The intriguing question at the heart of this investigation brings me full circle to the conundrum of the first narrative. The wow! factor that I accidently stumbled upon as a beginning teacher, and the unplanned phenomenon that I wasn't able to articulate at the time, or "teach" in my workshops, could not have been reasonably addressed because there were few scientific explanations and little scientific interest to substantiate the mysterious occurrence. "Only during the past decade has the problem finally entered the scientific agenda, largely as a part of the investigation of consciousness," says Damasio (2003, p. 184).

Damasio calls intuition "the covert, mysterious mechanism" by which we arrive at the solution of a problem without reasoning toward it (1994, p. 188). Because the creative process on which the progress of science is based operates on the level of the subconscious, when we witness signs of creativity in contemporary humans, explains Damasio, we are probably witnessing the integrated operation of sundry combinations of these devices. Damasio's astute, all-encompassing observation moves this investigation towards a broader comprehension of the link between identity and creativity and the important implications of "the integrated operation of sundry combinations of these devices" (p. 191) in the scientific investigation of consciousness as well as in a revised rationale for accommodating creativity in education.

\section{Making the Connection}

The aim of education, according to Christopher Winch (1999), is to prepare children for adult life. The purpose of schooling is to instruct, socialize, and qualify students for political, social, and economic utilitarian-instrumental advantages; however, the meaning of education (from the Latin root, educare, to draw forth from 
within) goes beyond the one-sided positivistic view of schooling. Deep within the heart of the educational matter, there is a persistent and determined search for self, a who that is not artificially engineered (i.e., moulded by concept and constructed by will), but originally generated and authentically expressed from within.

Understanding the mystery of identity and creativity requires that we "think what we are doing" (Arendt, 1974, p. 242); that we reignite the flame of intuition (Bergson, 1998/1907); and that we include emotion and feelings as integral aspects of reason (Damasio, 1994; 2003). Making the connection between what and who, knowing and thinking, intuition and intellect, and mind and body may turn out to be the real "job" of the modern-day educator. A dynamic interplay of the differences may make all the difference in how we envision ourselves in the future.

The concerns for the future of education as expressed by the educational leaders at the 2004 Oxford Round Table on Education challenge the status quo of modern schooling, and advocate a revised rationale for a reasonable accommodation of creativity. By all accounts, it would seem that a"revised view of human beings more accurate the one readily available" as articulated by Damasio $(2003$, p. 8), is in the hands (and minds and hearts) of educators. Reverberating from the hallowed halls of the Oxford Union are two remaining questions: Is there room for creativity in our schools? How could/would creativity contribute to nurturing and nourishing the fragile well-being of the interdependent, interconnected worldwide web?

The more I understand the mystery at the heart of this investigation, the more I doubt the sustainability of present-day conceptualizations of constructed identity and instrumental productivity as useful rationales for success in Western school programs and reforms. The propensity for savoir faire (knowledge and skills) no longer seems feasible if we are to take seriously into account the list of all-toofamiliar problems cited by Bill Laar and the delegates at the 2004 Oxford Round Table. In advocating room for creativity, the educational leaders envisioned the possibility of moving toward a well-rounded education that would include both savoir faire (knowledge and skills) and raison d'être (meaning and purpose). The health (wholeness) of the interconnected, interdependent world in which we live might very well hang in the balance. 


\section{Conclusion}

Visionary educational scholar Maxine Greene (1995) defines educating for freedom as letting people choose their own way of being in the world. She sees in imagination the untapped inner resources of youth. Of the "in-between" (Arendt, 1974) that opens between people when they come together as who, Greene says, "There are worldly relationships, and over that, there is the delicate web of human relationships" (1998, p. 23).

The delicate web of human relationships that I have experienced in schools tells me that creativity does not need money as much as it needs will. When room is made for creativity in the hearts and minds of educators (room for who we are, and room for the "in between"), I am convinced that all manner of means will quickly materialize to accommodate the intangible wow! factor. As I recall school life-the vibrancy of reading circles, the excitement of awards assemblies, the exuberant allschool singing, the dancing, the musical production extravaganzas, the costumes, the artwork displays, the science fairs, the hard work, the lunch-hour sports, the mathematics videos, the larger community involvement, the partnerships with universities, the student council's voices, and the tension-filled growing pains generated between stakeholders in the collaborative creation of their school's Success Plan-I can vouch for the fact that creativity (the "real" we have in common, Arendt, 1974) does not cost money that cash-strapped public schools just don't have. As one teacher put it very simply, "When we're together, stuff happens!"

\section{References}

Arendt, H. (1971). Thinking and moral considerations: A lecture. Social Research, 38(3), 417-446.

Arendt, H. (1974). The human condition. Chicago: University of Chicago Press.

Barone, T., \& Eisner, E. (1997). Arts-based educational research. In Jaeger, R. (Ed). Complementary methods for research in education, 2nd edition, Washington, DC: AERA.

Bergson, H. (1907). L'Evolution créatrice. Paris: PUF (Publication universitaire française).
Bergson, H. (1998). Creative evolution, Authorized Translation by Mitchell, A. Mineola, NY: Dover Publications, Inc.

Damasio, A. R. (1994). Descartes' error: Emotion, reason and the human brain. New York: G.P. Putnam's Sons.

Damasio, A. R. (1999). The feeling of what happens: Body and emotion in the making of consciousness. New York: A Harvest Book, Harcourt, Inc.

Damasio, A. R. (2003). Looking for Spinoza: Joy, sorrow and the feeling brain. Orlando, FL: Harcourt Books. 
Damasio, A. R. (2010). Self comes to mind: Constructing the conscious brain. New York: Pantheon Books.

Gadamer, H.G. (2011). Truth and method (c. 1975) Translation revised by Weinsheimer, J. \& Marshall, D.G. New York: Continuum International Publishing Group.

Greene, M. (1995) Releasing the imagination: Essays on education, the arts and social change. San Francisco: Jossey-Bass.

Greene, M. (1998). A light in dark times: Maxine Greene and the unfinished conversation. In Maxine Greene, William C. Ayers, and Janet L. Miller (Eds.). Teachers College Press.
Hall, S., \& Du Gay, P. (Eds) (1996). Question of identity: Debates about cultural identity and their meaning in contemporary social formations. London: SAGE Publications.

Hendry, P.M. (2010). Narrative as inquiry. The Journal of Educational Research, 103, 72-80

Taylor, C. (1989). Sources of the self: The making of modern identity. Cambridge, MA: Harvard University Press.

Winch, C. (1999). The aims of education. In Roger Marples (Ed). London: Routledge (pp. 74-84).

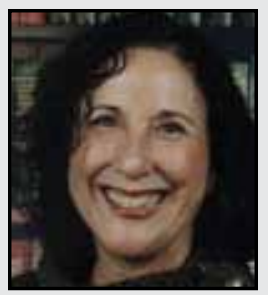

Margaret Dobson was previously a high school teacher of French and English and an educational leader in Ontario and Quebec schools. She has recently returned to her alma mater to investigate intuitive educational hunches she has gleaned from the field. She is a PhD Candidate in the Department of Integrated Studies in Education at McGill University. Her research interests include the potential role of identity and creativity in revitalizing the meaning and purpose of education. 